на оновленому стилі та видозміні інтонаційної й тематичної сфери образів. Засоби музичної виразності постійно урізноманітнюються та розвиваються, що робить звучання особливим і ні на що не схожим. Таким чином, українські композитори впевнено вносять елементи сучасної музики в дитячу фортепіанну літературу.

\section{СПИСОК ВИКОРИСТАНОЇ ЛІТЕРАТУРИ}

1. Барвінський В. Колядки і щедрівки на фортеп'ян 3 підложеним текстом / В. Барвінський. Львів : Видання Музичного товариства ім. М. Лисенка, 1935. -24 c

2. Булка Ю. Нестор Нижанківський: життя і творчість / Ю. Булка. - Львів ; Нью-Йорк : вид-во М. П. Коць, 1997. - 60 c

3. Кабалевський Д. Як розповідати дітям про музику / Д. Кабалевський. - К. : Музична Україна, 1982. $320 \mathrm{c}$.

4. Мозгальова Н. Г. Виховні можливості фортепіанної музики для дітей / Н. Г. Мозгальова. URL: https://library.udpu.edu.ua/library files/psuh pedagog probl silsk shkolu/9/visnuk_23.pdf (дата звернення: 02.09.2109).

УДК 781.43+786.2.002(045)

DOI: 10.37026/2520-6427-2019-100-4-173-177
5. Милич Б. Фортеп’янна література українських радянських композиторів для дітей та юнацтва / Б. Милич. - К. : Держ. вид. обр. мист. і муз. літ. УРСР, 1961. $-104 \mathrm{c}$.

6. Ніколаї Г. Ю. Українська фортепіанна музика як феномен культури 20 століття / Г. Ю. Ніколаї. URL: https://scholar.google.com.ua/citations?user=y5ATWyY AAAAJ\&hl=ru (дата звернення: 29.08.2019).

7. Олійник О. Українська фортепіанна музика для дітей / О. Олійник. - К. : Наук. думка, 1979. - 107 с.

8. Рудницька О. П. Музика і культура особистості: проблеми сучасної педагогічної освіти [Текст] : навчальний посібник / О. П. Рудницька ; АПН України, Інститут педагогіки. - К. : [б. в.], 1996. - 247 с.

9. Скорик М. Твори для фортепіано : навчально-методичний посібник / М. Скорик. - Львів : Сполом, 2008. - 220 с.

10. Тимощук О. Фортепіанні цикли для дітей у творчості українських композиторів: образно-художній аспект : автореф. дис. на здобуття наукового ступеня канд. мистецтвознавства : спец. 17.00.03 «Музичне мистецтво» / О. Тимощук. - Одеса, 2011. - 18 с.

Дата надходження до редакиії: 05.09.2019 p.

\section{Станіслав ДИМЧЕНКО,}

професор кафедри народних інструментів

Інституту мистеитв Рівненського державного

гуманітарного університету,

заслужений працівник культури Украӥни,

відмінник освіти Украӥни

Іван КАЛАШНІКОВ,

студент магістратури кафедри народних інструментів Інституту мистецтв Рівненського державного гуманітарного університету

\title{
МУЗИЧНА ОРНАМЕНТИКА ТА ÏЇ РОЛЬ У ФОРМУВАННІ ВИКОНАВСЬКОЇ МАЙСТЕРНОСТІ СТУДЕНТІВ КЛАСУ БАЯНА
}

У статті розглянуто специфічні особливості виконання музичної орнаментики на баяні, зокрема проаналізовано особливості виконавської орнаментики з урахуванням музики різних жанрів, епох, стилів, а також окреслено виконавську інтерпретацію мелізмів на баяні.

Ключові слова: орнаментачія, прикраса, мелізми, трель, форшлаг, мордент, групето.

B статье рассмотрень специфические особенности исполнения музыкальной орнаментики на баяне, в частности проанализированы особенности исполнительской орнаментики с учетом музыки разных жанров, эпох, стилей, а также описана исполнительская интерпретация мелизмов на баяне.
Ключевые слова: орнаментачия, украшения, мелизмы, трель, групетто, форшлаг, мордент.

The article discusses issues that continue to further explore various aspects of the development of bayan music, questions of a detailed study of artistic features and style professional works for folk instruments, which defined in modern musicology as the starting point in the process of professionalization and acculturation of this field of performing arts.

On the basis of the analysis of fundamental works of famous scientists - musicologists and music teachers, the question is raised about the urgency of the development of problems related to the correct implementation of textual means of expression, in particular, melismism, 
which is an important criterion for determining the level of musical maturity of the performer, his professional skill, as well as his level of formation as a future teacher of professional disciplines. As a result of the research, an attempt was made to study and reveal the specific features of the performance of musical ornamentation on the bayan.

Synthesis of musicological theoreticalgeneralizations and practical pedagogical works on performance of musical characteristics on folk instruments is analyzed. It is justified that melisms are not just decorations, but also powerful means of musical expression. And if their expressiveness is determined by the nature of the melody and the value of the notes being marked, then the functions of the melisms can be varied.

Key words: ornamentation, embellishment, melizm, trill, gruppetto, grace note, mordent.

Постановка проблеми. Уміння музиканта виконувати музику, багату на текстологічні засоби виразності, правильно розшифровувати та використовувати музичні позначення є свідченням високого рівня його музичної зрілості, професійної майстерності та відчуття стилю.

Неабияку роль при цьому відведено мелізмам невеликим мелодичним прикрасам як одному із різновидів музичної орнаментики. Завдяки мелізмам можна значно покращити звучання твору, збагатити його новим звучанням, наповнити яскравою образністю. Специфіка мистецтва виконання мелізмів на баяні спонукає майбутнього викладача приділяти означеному питанню особливу увагу, використовуючи при цьому музику різних жанрів та епох.

Аналіз наукових досліджень і публікацій. Аналіз виконавської орнаментики з урахуванням музики різних епох і стилів висвітлено у працях К. Баха [1], Н. Голубовської [2], Ф. Куперена [7], В. Ландовської [8] та ін.

Мистецтво виконання музичної орнаментики на музичних інструментах, зокрема баяні, представлено в наукових дослідженнях М. Давидова [3], Ф. Ліпса [9], В. Семенова [10], А. Семешка [11] та ін.

Мета статті - охарактеризувати специфічні особливості виконання музичної орнаментики, зокрема мелізмів, на баяні.

Виклад основного матеріалу. Яку роль відіграє музична орнаментика в музиці? Ось як про це роздумує К. Бах: «Ніхто не сумнівається у необхідності мелодичних прикрас. Вони, насправді, - незамінні, адже пов'язують і оживляють ноти, надають їм особливої сили та ваги, роблять їх привабливими, допомагають прояснити зміст п'єси. Завдяки їм можна покращити доволі посередній твір і навпаки - найкраща тема без них буде здаватися невиразною та безглуздою...» [1].

Бажання музикантів прикрасити мелодію додатковими звуками існувало давно. Поява мелодичних прикрас передусім пов'язана із мистецтвом імпровізації. Тривалий час музикантами вони ніде не фіксувалися, тобто не записувалися, оскільки сфери композиторства та виконавства чітко не розмежовувалися між собою: виконавці були композиторами, а композитори - виконавцями, саме вони на власний розсуд застосовували різні мелодичні доповнення прикраси, які робили музику більш безпосередньою, яскравішою, сповненою індивідуальності.

Прикраси в музиці зазвичай використовувалися у двох випадках: для «зв’язку» та для «блиску». Перші поєднували далеко розташовані між собою мелодичні ноти, заповнювали порожнечу довгих тривалостей та продовжували їх звучання; другі - пожвавлювали мелодичну тканину твору, загострювали увагу на конкретній ноті, підкреслюючи завдяки цьому іï значення.

Спочатку ці прикраси називали манерами (від нім. мanieren), пізніше в музичному мистецтві з'явився спеціальний термін, яким їх почали характеризувати, - орнаментика.

Орнаментика (від лат. ornamentum - прикраса) - це мелодичні звороти зі звуків невеликої тривалості, що прикрашають основний мелодичний малюнок, а також посилюють його експресивність, дають виконавцям додаткову можливість продемонструвати свою майстерність; розширюють масштаби твору, ускладнюють інтонаційно-ритмічний зміст мелодії. Звуки орнаментики, як правило, більш короткі, ніж основні звуки мелодії, завдяки чому вони пожвавлюють мелодичний рух, динамізують музичний розвиток.

У музичній практиці побутують два види орнаментики: обов'язкова орнаментика (групето, мордент, форшлаг, трель та ін.), позначена в нотах; імпровізаційна орнаментика (колоратура, дулади, трелі та ін.), яку виконавець обирає на власний розсуд.

До орнаментики належать: пасажі, тиради, мелізми, фігурації, фіоритури, колоратура, голоси та ін.

Мелізми (від грецьк. теlisma - гімн, мелодія) це невеликі, стійкі за формою мелодійні прикраси, які мають умовні позначки. До мелізмів відносять форшлаг, групето, подвійний мордент, перекреслений мордент, подвійний перекреслений мордент, трель та ін. [12; 16].

У мелізмах, як і в інших видах техніки, необхідно враховувати баянну специфіку звукоутворення i звуковидобування. Передусім це стосується співвідношення динаміки мелодичних тонів, що утворюють прикраси [10, с. 43].

У контексті нашого дослідження важливо встановити, яку роль у музиці відіграє все те, що стоїть за назвами «прикрасами», «манерами», «мелізмами». Якщо ці терміни розглядати у їх прямому значенні, то під мелізмами у музичних творах варто розуміти не лише щось «ошатне», що використовується для «блискучості» твору, аби оживити його музичне полотно, виділити значення кожної ноти, а й те, що застосовується з метою усунення порожнеч між довгими нотами та подовження звучання останніх.

Обираючи для студентів-баяністів матеріал для роботи 3 означеної тематики (статті, дослідження, монографії тощо), можна, наприклад, запропонувати їм скористатися «таблицею розшифрування прикрас» (див. рис. 1), створеною свого часу Й. С. Бахом для дев'ятирічного сина Вільгельма Фрідемана та вміщеною у «Нотній книжці», або подібною таблицею французького композитора д’Англебера (див. рис. 2), яка, на думку музичних критиків, стала своєрідним зразком для таблиці Баха.

«Порівнюючи ці два історичні документи, - зауважує А. Семешко, - неважко виявити безперечний вплив французької музики на музичні смаки Баха» $[11$, с. 123$]$. Однак все ж слід зазначити, що виконання прикрас композиторів епохи бароко не може базуватися виключно на власному смаку виконавця чи викладача, адже смак завжди грунтується на суб'єктивних відчуттях, відображає ступінь музичної освіти баяніста. Найкращою «школою» для розшифрування мелізмів може і повинно бути лише звернення до музичної літератури та авторських розшифрувань композиторів, які наявні безпосередньо в нотному тексті. 


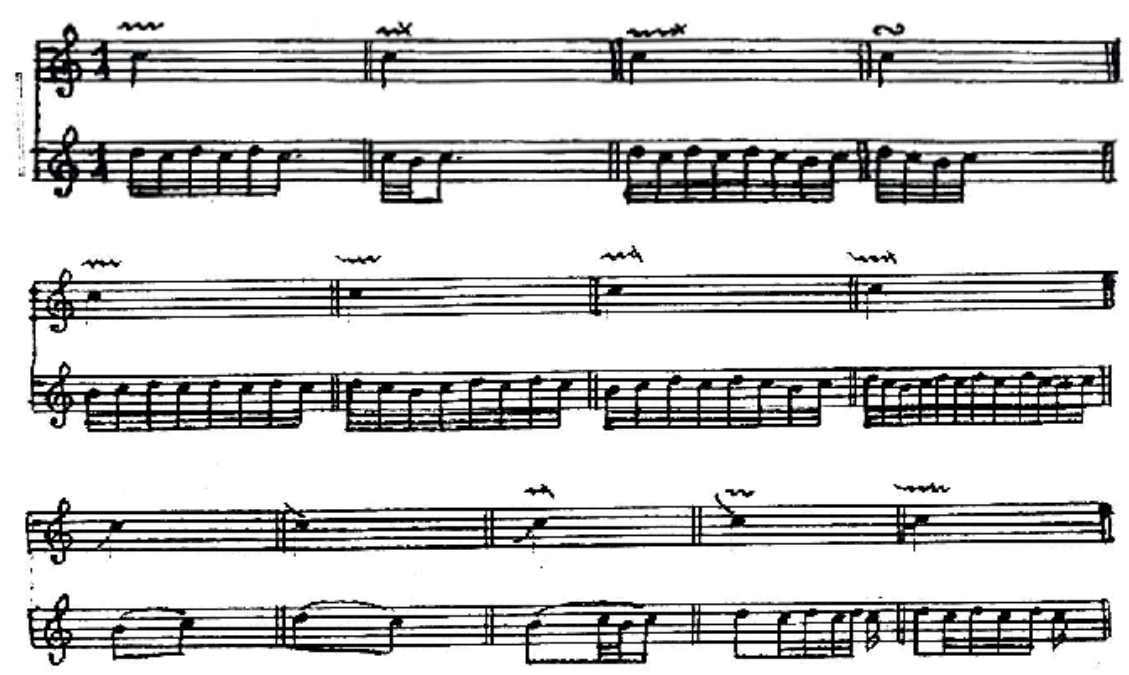

Рис. 1. Таблиия розшифрування прикрас Й. С. Баха
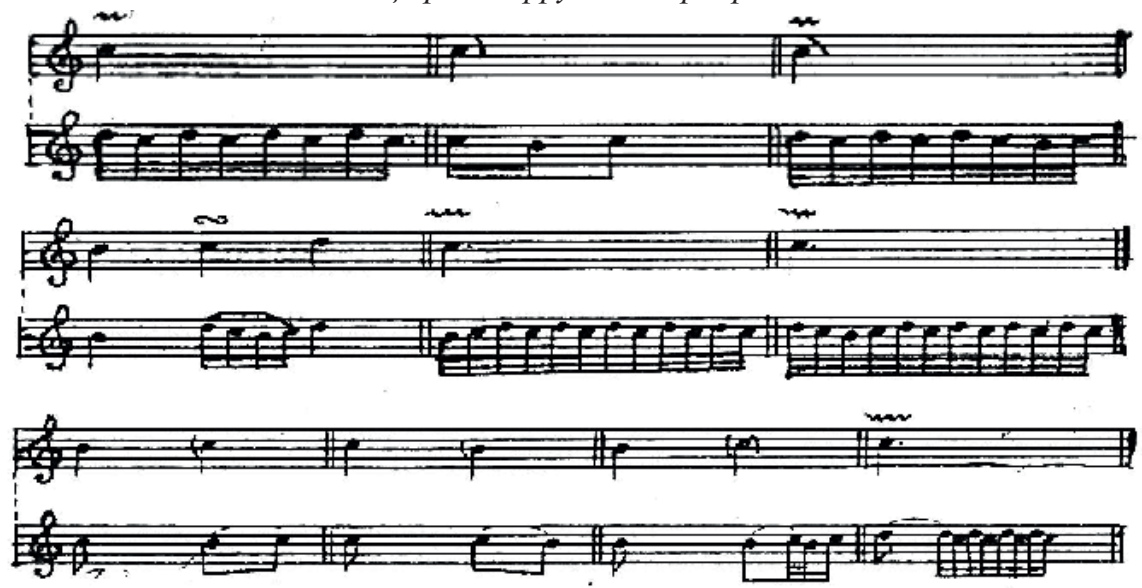

Рис. 2. Таблиия розшифрування прикрас Х. д’Англебера

Отже, на підставі вищесказаного можемо зазначити, що мелізми - це не просто прикраси, а ще й потужний засіб музичної виразності.

Розглянемо деякі види мелізмів, пам'ятаючи про те, що їх виразність визначається характером мелодії і значенням нот, які орнаментуються. У зв'язку з цим у сучасній нотації вони отримали постійну форму запису(див. рис. 3):
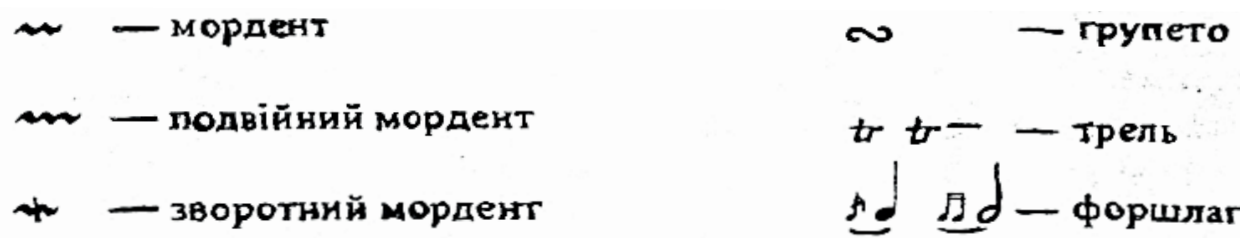

廿 подвійний зворотний мордент

Рис. 3. Види мелізмів та приклади їх запису

Охарактеризуємо деякі із них докладніше.

Форилаг (від нім. Vorschlag - пердудар) - коротка мелодична прикраса з одного, двох або більше звуків, що виконується перед основним звуком мелодії або акорду [12, с. 425]. Форшлаги вживаються як для акцентування, так і для мелодизації. Існують короткі та довгі форшлаги. Короткий форшлаг записується перекресленою восьмою нотою 3 хвостиком, виконується за рахунок основної чи попередньої ноти та використовується переважно для акцентування; довгий - як засіб мелодизації та позначається маленькою нотою біля основної ноти, що зменшує їі тривалість на свою величину.

Особливу роль форшлагів відзначав К. Ф. Бах: «Вони так само удосконалюють мелодію, як і гармонію. Усі синкопи і дисонанси можна звести до форшлага - a що таке гармонія без цих двох елементів?» [1, с. 59].

В. Ігонін, аналізуючи процес розшифрування форшлагів у творах Й. С. Баха на баяні, зазначає, що «відмінність короткого форшлагу від довгого полягає в тому, що змістовне значення інтонації припадає на основну ноту. 
Форшлаг надає мелодичній опорі блискучості, гостроти, підкреслює іiі роль. Короткий форшлаг активізує мелодичний рух. Форшлаг повинен бути коротким, щоб не порушувати ритмічного руху» [5, c. 19-21].

Академік М. Давидов зі свого боку переконує: «Недостатня сфокусованість ривка міха в потрібну метричну точку призводить до непередбаченого акцентування першого звука. Чіткість же основної долі на баяні в таких випадках згладжується лігою. Запобігаючи небажаним зміщенням динаміки, форшлаг треба розпочати з м'якої атаки, а основний звук - у точному співвідношенні натискання клавіші 3 ривком міха». Складну виконавську проблему становить частота ривків міха у сполученні форшлагу з основним звуком малої тривалості. Цей навик здобувається в результаті тривалої роботи в повільному темпі. Тобто, необхідно прагнути повної синхронності рухів пальців і міха. Правильне співвідношення динамічних напружень у форшлагах досягається шляхом використання агогічного акценту на основній ноті. При цьому потрібна звукова чистота, «акустична сухість» зв'язку форшлагу 3 основною нотою. У форшлагах, які виконуються за рахунок тривалості основної ноти, обов'язкова активність атаки першого звука. Недостатня увага до характеру атаки звука призводить до механічного зміщення акценту на останню ноту мелізму. Форшлаги, що виконуються на баяні легатисимо, звучать громіздко, ритмічно неяскраво. Для артикуляції чіткості їх можна виконувати, застосовуючи «перлинну» техніку леджієро або глісандо» [3, с. 172-173].

Таким чином, в одних випадках форшлаг може займати половину тривалості ноти, а в пожвавлених пасажах - бути достатньо гострим. Якщо у форшлазі підкреслюється затримка, то цей дисонуючий тон може бути виділеним. В інших випадках форшлаг не варто виділяти, а підкреслювати основний тон, розташований на більш слабкій долі такту - тоді утворюється наспівна синкопа. Короткий форшлаг між великими інтервалами повинен програватися швидко. Таким своєрідним стрибком він підкреслює атаку головної ноти. Короткий форшлаг повинен співпадати 3 басом, «тоді він, завдяки раптово дисонуючому звучанню, звучить більш гостро» [13, с. 113], однак динамічна перевага належить головній ноті.

Відомо, шо швидкість форшлагу залежить від характеру музики. Довгий форшлаг звучить стільки, скільки потребує його тривалість. Зокрема, існує правило: якщо прикраса стоїть перед дводольною нотою, то забирає половину іiї тривалості, а якщо перед тридольною - то одну або дві третини. При цьому вона надає й наголос, що падає на основний тон. Художній зміст довгого форшлагу полягає в тому, що розв'язку слід грати тихіше.

Цікавий підхід до розкриття суті трелі ми знаходимо в монографії М. Давидова «Теоретичні основи формування виконавської майстерності баяніста» [3], де автор зазначає: «Трель являє собою елемент рухливості пальців. Відомо, що сила звучання трелі на баяні не залежить від сили удару пальців. Швидкість і рівність трелі визначається ритмічною упорядкованістю економних рухів, що успішно формується при постійному, безперервному контакті із поверхнею клавіатури. Дрібна м'язова вібрація повинна давати густу трель без утоми руки. При тривалій трелі необхідно слідкувати за свободою апарату.
Не виключене використання й допоміжних, обертових рухів кисті, інколи навіть передпліччя.

На трелі виконавець тренується в максимальній наближеності руки до клавіатури, у свободі та економності швидких рухів, що складають основу рухливості пальців. Після настроювання руки на трелі легко перейти до швидкого руху в гамі, поширюючи відчуття трелі на поступеневий потік звуків.

Швидка і зв'язна трель виконується звичайно 2, 4-м пальцями від першого на третій ряд; 2, 3-м пальцями від першого на другий ряд; 3, 4-м пальцями від другого на третій ряд. Для посилення чіткості трелі інколи можна робити підміну пальців (3, 2-й) у першому ряду, зберігаючи 4-й палець на другому або 4-й - на третьому ряду.

Із метою вдосконалення трелі можна застосувати гру непарних ритмічних груп тріолей або квінтолей. Періодичне перенесення опори доцільне при цьому як засіб підвищення точності удару кожного пальця, реактивності м'язових імпульсів та ритмічності рухів. Для вироблення рівності трелі можна використати ваговий спосіб гри, а також названі нами вище прийоми рухів (перлинна техніка, леджієро, мелодійна гра, стакато). У швидкому темпі трель на баяні найчастіше виконується легким рухом пальців при використанні коротких м'язів» [3, с. 172-173].

Цікавою для нашого дослідження $є$ праця Н. Кашкадамової «Мистецтво виконання музики на клавішно-струнних інструментах», де, зокрема, зазначається, що в кожному окремому випадку довжина трелі повинна бути вирішена, зважаючи на конкретні умови, адже ніхто не буде виконувати іiі, дотримуючись арифметично точного ритму. Насамперед слід ураховувати зміст, задум, почуття мелодичної фрази, контекст твору [6, с. 194].

Групето (від італ. grupреtto - маленька група) мелодична прикраса з групи мелізмів, що об'єднує 4 - 5 звуків і зображується в нотації спеціальним значком виставленим над однією або двома різними нотами, що створює передумови для різних варіантів розшифрування [16, с. 58]. Використовується зазвичай як елемент для зв'язування звуків та активізації мелодичного руху (переважно в затакті).

Існують різні способи виконання групето: над нотою, поміж нотами, після нот із крапкою, знизу ноти. Виконуючи групето, слід пам'ятати, що означена фігура визначає тон, до якого спрямована. Такий тон завжди розташований на відносно сильній долі такту. У пунктирному ритмі групето зупиняється на основній ноті, аби запобігти наданню непотрібної енергії ноті, що проходить на найслабшій долі такту. Групето над нотою починається з наступної більш високої ноти і виконується на сильній долі такту. Така фігура складатиметься із трьох нот. Групето із чотирьох нот утворюється у тому випадку, якщо основна нота $\epsilon$ ланкою мелодичної лінії. Залежно від характеру музики групето поміж нотами може починатися раніше або пізніше. У повільному темпі групето виконується переважно дещо пізніше половини тривалості першої ноти, а в пожвавленому - шляхом оспівування основного тону сусідніми. Виконання групето після ноти з крапкою залежить від характеру музики, тому воно не завжди складається із чотирьох нот однакової тривалості. 
Ф. Ліпс у своєму посібнику «Мистецтво гри на баяні» у зв'язку з цим пише: «Тривалість звучання на баяні, якщо іiі невміло використовувати, може негативно відобразитися на логічності розгортання мелодичної лінії, що нерідко спостерігається у виконанні групето учнями» [9, с. 78].

Мордент (від італ. ordent - кусючий, гострий) музична прикраса, в якій між повтореним основним звуком береться верхній або нижній допоміжний звук. Існують прості та подвійні морденти, які нагадують коротку трель. Кожен із них може бути прямим або зворотним [16, с. 161].

Морденти, подібно до коротких форшлагів, - це спосіб підкреслити основний тон, його акцентування. Виконується він за рахунок головного часу, проте у випадку, коли перед нотою із мордентом розташована нота, довша за тривалістю, і якщо цього вимагає характер мелодичної лінії, мордент прозвучить краще, якщо його виконати перед нотою, яку він прикрашає. Однак варто уникати співпадіння ритму мордента із ритмом іншого голосу, адже він позбавить його забарвлення. Добре звучання мордента спостерігається тоді, коли його виконувати швидко, роблячи акцент на першій ноті, та закінчити до появи наступної восьмої у верхньому голосі.

Ф. Ліпс упри цьому наголошує: «До виконання прикрас в оригінальних творах для баяна слід відноситися так само уважно, як і до арсеналу орнаментації, що міститься у творах старовинних майстрів» [9, с. 80]. Так, про правила виконання прикрас не слід забувати у «Концертній сюїті» М. Чайкіна, написаній у традиціях старовинних зразків цього жанру. Лише за таких умов музика збереже притаманний їй характер. У середній частині цього твору - «Сарабанді» - форшлаги прозвучать стильно, якщо виконати їх за рахунок головної долі. А от у «Думці» Г. Шендерьова слід уникати співпадіння ритму мелодії й акомпанементу, тоді як у «Ліричному вальсі» М. Чайкіна часто порушується сама суть праллера. Ознаки стилізації старовинної музики знаходимо також у першій частині «Концертного триптиху» Катті, де серед інших наявне застосування форшлагів.

Щодо сучасних композиторів, то вони зазвичай виписують прикраси в тексті, докладно розшифровуючи їх при розписуванні. Наприклад, виписані трелі трапляються у таких творах, як: «Весела хвилинка» В. Магіденка (праллер); третій частині «Сюїти» О. Холмінова (групето); третій частині «Концертної сюїти» М. Чайкіна (довгий форшлаг) та ін. [3, с. 109-111].

Висновки. Таким чином, нами було проаналізовано найбільш розповсюджені способи виконання прикрас, з якими стикаються студенти-баяністи кафедри народних інструментів, майбутні викладачі фахових дисциплін під час вивчення предметів «Основний музичний інструмент», «Методика викладання гри на музичних інструментах», «Методика роботи над педагогічним репертуаром».

Зазначимо, що завдяки орнаментиці, зокрема мелізмам, можна краще передати стиль та епоху музичного твору, збагатити художній зміст та наповнити його яскравою образністю, що є частиною важливих та обов'язкових знань і вмінь майбутнього викладача фахових дисциплін.

Крім того, студентам необхідно пам'ятати, що на практиці вони можуть стикатися з певними змінами у розшифровуванні тих чи інших прикрас, однак це не варто перетворювати на догму. У будь-якому випадку прикраси слід виконувати таким чином, щоб вони звучали і поєднувались з іншими звуками природно, плавно та вільно.

Насамкінець хочемо навести слова Р. Вагнера, які, впевнені, стануть дороговказом для молодих музикантів: «Діти мої, звертайте увагу на маленькі ноти великі підуть самі по собі».

\section{СПИСОК ВИКОРИСТАНОЇ ЛІТЕРАТУРИ}

1. Бах К. Ф. Э. Опыт истинного искусства клавирной игры / К. Ф.Э. Бах ; пер. и ком. Е. Юшкевич. СПб.: EARLYMUSIC, 2005. - T. 1. - 170 c.

2. Голубовская Н. Что нужно знать о мелизмах / Н. Голубовская // О музыкальном исполнительстве. Л. : Музыка, 1985. - С. 5-21.

3. Давидов М. А. Теоретичні основи формування виконавської майстерності баяніста (акордеоніста) / М. А. Давидов // Підручник для вищ. та серед. муз. навч. закладів. - К. : Муз. Україна, 2004. - 290 с.

4. Друскин М. С. Клавирная музыка Испании, Англии, Нидерландов, Франции, Италии и Германии XVI - XVIII веков / М. С. Друскин. - Л. : Гос. муз. издат., 1960. $-282 \mathrm{c.}$

5. Игонин В. Г. Некоторые особенности интерпретации произведений И. С. Баха на баяне / В. Г. Игонин // Методика обучения игры на народных инструментах / [сост. П. Говорушко]. - Л. : Музыка, C. 19-33.

6. Кашкадамова Н. Б. Мистецтво виконання музики на клавішно-струнних інструментах / Н. Б. Кашкадамова. - К. : Освіта України. - 2009. - 416 с.

7. Куперен Ф. Искусство игры на клавесине / Ф. Куперен. - М., 1973. - 152 с.

8. Ландовская В. Старинная музыка: пренебрежение к старинным мастерам. Сила звучности. Стиль. Исполнение. Виртуозы. Меценаты в музыке / В. Ландовская. - М. : Б. П. Юргенсон, 1913. - 133 с.

9. Липс Ф. Р. Искусство игры на баяне / Ф. Р. Липс. - М., 1985. - 158 с.

10. Семенов В. А. Современная школа игры на баяне / В. А. Семенов. - М., 2004. - 216 с.

11. Семешко А. А. Виконавська майстерність баяніста / А. А. Семешко // Методичні основи : навч. посібник. - Тернопіль : Навчальна книга - Богдан, 2009. - 144 c.

12. Хоркава Л. Український музично-педагогічний словник / Л. Хоркава. - Львів, 2010. - Т. 2. - 513 с.

13. Шубіна В. Б. Використання текстологічних засобів виразності (мелізмів) у фортепіанній практиці / В. Б. Шубіна // Актуальні питання мистецької педагогіки. - Хмельницький пед. ун.-т. - 2015. Вип. 4. - С. 112-116.

14. Швейцер А. Иоганн Себастьян Бах / А. Швейцер. - М. : Музыка, 1965. - 726 с.

15. Юровский А. А. Филипп Эммануил Бах, его биография, фортепианное творчество и система орнаментики / А. А. Юровский // Избранные сочинения для фортепиано / Ф. Э. Бах. - М. = Л., 1947. Ч. XXVII.

16. Юцевич Ю. Є. Музика : словник-довідник / Ю. Є. Юцевич. - Тернопіль : Навч. книга - Богдан, 2003. $-352 \mathrm{c}$.

Дата надходження до редакиії: 07.10.2019 p. 